Journal An-Nafs: Kajian Penelitian Psikologi

https://ejournal.iai-tribakti.ac.id/index.php/psikologi

e-ISSN: 2549-6166

p-ISSN: 2528-0600

DOI: $10.33367 /$ psi.v5i1.1122

Submitted: 2020-04-06

Revised : 2020-04-23

Accepted : 2020-04-28

Published: 2020-06-01

\title{
RELIGIUSITAS DAN INTENSI ANTI KORUPSI: PERAN MODERASI KEBERSYUKURAN
}

\author{
Humaira Mumtazah' ${ }^{1}$, Agus Abdul Rahman ${ }^{2}$, Sarbini $^{3}$ \\ 1a_abdurrahman72@yahoo.com, 2agus.abdulrahman@uinsgd.ac.id, ${ }^{3}$ sarbini@uinsgd.ac.id
}

UIN Sunan Gunung Djati Bandung

\begin{abstract}
Corruption is a behavior that cannot be socially or religiously justified. Interestingly, despite the corruption is prohibited in all religions in Indonesia, the index of corruption remains high as reported by the results of surveys of national and international institutions. Besides, research on this matter showed inconsistency in the relationships between religiosity and corrupt behavior. This research re-examined the relationship between religiosity and anticorruption intentions and determined the moderating effect of gratitude as an intervening variable. Gratitude is one of the strongest religious values which is expected to reduce ones' intention to do corruptions. The research was conducted using a correlational research design, involving 92 population in an educational foundation in Garut regency, West Java. Data were collected using the GRAT short form to measure gratitude and the Muslim Religiosity Scale (MRC) was employed to measure religiosity. Whereas, Anti-Corruption Intention Scale was used to measure the anti-corruption intention. The results of data analysis showed that religiosity and anti-corruption intentions were positively correlated ( $F=$ $154.1, p=.001, R 2=.631$ ), and gratitude moderated the increase in the relationship ( $R 2=$ .668). Therefore, gratitude was regarded as an intervening variable that strengthened the correlation between religiosity and anti-corruption behavior by $3.7 \%$.
\end{abstract}

Keyword: Gratitude, Religiousity, Anti-corruption intention

\begin{abstract}
Abstrak
Perilaku korupsi merupakan perilaku antisosial yang tidak dibenarkan baik secara sosial maupun agama. Menariknya, walaupun agama jelas-jelas melarang korupsi, angka korupsi di Indonesia yang dikenal sebagai negara yang masyarakatnya religius justru terbilang cukup tinggi. Hal ini merujuk pada berbagai lembaga survei di dalam maupun di luar negeri. Selain itu, beberapa penelitian menunjukkan adanya ketidakonsistenan antara religiusitas dengan intensi dan perilaku korupsi. Pada penelitian ini, selain akan diuji kembali hubungan antara religiusitas dan intensi anti korupsi, jua akan diuji pengaruh moderasi variable kebersyukuran terhadap hubungan antara keduanya. Variabel kebersyukuran dipilih karena termasuk salah satu nilai yang sangat penting dalam agama, dan diduga akan menurunkan intensi untuk korupsi. Penelitian dilakukan dengan menggunakan rancangan penelitian korelasional. Dengan menggunakan penelitian populasi, terdapat 92 subjek di salah satu yayasan pendidikan di kabupaten Garut Jawa Barat. Data penelitian dikumpulkan dengan menggunakan GRAT short form untuk mengukur gratitude, Muslim Religiosity Scale (MRC) untuk mengukur religiusitas, dan Skala Intensi Anti Korupsi untuk mengukur intensi anti korupsi. Hasil analisis data menunjukkan bahwa religiusitas dan intensi anti korupsi berkorelasi secara positif ( $\mathrm{F}=$ 154.1, $p=.001, \mathrm{R}^{2}=.631$ ), serta kebersyukuran sebagai moderator dapat meningkatkan
\end{abstract}


Humaira Mumtazah dkk. | Religiusitas dan Intensi Anti Korupsi

hubungan antara keduanya $\left(\mathrm{R}^{2}=.668\right)$. Artinya, kebersyukuran dapat meningkatkan hubungan antara religiusitas dan intensi anti korupsi sebesar sebesar 3.7\%.

Kata Kunci: Kebersyukuran, Religiusitas, Intensi anti korupsi

\section{PENDAHULUAN}

Korupsi merupakan salah satu masalah serius yang dihadapi bangsa Indonesia. Berdasarkan survey Transparency International (2017) mengenai indeks persepsi korupsi di 180 negara, Indonesia merupakan negara terkorup ke-96 setelah Sri Lanka dan Timor Leste. Sementara itu, dilansir dari Tempo (19/12/2018), selama rentang 2018, KPK (Komisi Pemberantasan Korupsi) telah menerima sebanyak 6.202 aduan masyarakat terkait korupsi. Dari aduan tersebut, sebanyak 3.990 laporan terindikasi sebagai tindak pidana korupsi dan 2.153 laporan lainnya tidak terindikasi tindak pidana korupsi.

Berdasarkan data KPK, jumlah kasus korupsi cenderung meningkat tiap tahunnya. Selama rentang 2004 hingga 2018, ditinjau dari jenis perkara, tindakan korupsi yang paling banyak terjadi adalah penyuapan dan pengadaan barang/jasa. Sementara itu berdasarkan database putusan MA (Mahkamah Agung) tahun 2015, pelaku korupsi ditinjau dari jenis pekerjaannya paling banyak adalah PNS (Pegawai Negeri Sipil) yaitu sebanyak 1.115 orang atau 43,64\%, swasta dan lainnya (26,22\%), politisi (21,88\%), BUMN/D (5,83\%), serta lembaga independen (2,43\%). Pada semester I tahun 2018, ICW (Indonesia Corruption Watch) menyatakan bahwa pelaku korupsi terbanyak adalah ASN (Aparatur Sipil Negara) dengan jumlah 101 orang (Kompas, 2018). Rekapitulasi data tahun 2015-2018 dari BKN (Badan Kepegawaian Negara) menunjukkan bahwa terdapat 2.357 orang pelaku korupsi yang berstatus sebagai PNS (Pegawai Negeri Sipil). Data-data ini mengindikasikan dari tahun ke tahun pelaku korupsi terbanyak adalah PNS (Kompas.com, 2018)

Diantara bidang yang rawan korupsi adalah bidang pendidikan. Bidang pendidikan, mendapatkan alokasi dana yang sangat besar. Pada tahun 2018, misalnya, pemerintah mengalokasikan dana untuk bidang pendidikan sebesar $20 \%$ atau sekitar Rp. 444,31 triliun (Sekretariat Kabinet Republik Indonesia, 2018). Namun, dana tersebut tidak sepenuhnya dinikmati oleh masyarakat. Sebagiannya dikorupsi dan digunakan untuk kepentingan pribadi ataupun kelompok.

Di salah satu yayasan pendidikan di kabupaten Garut Jawa Barat, peneliti menemukan fenomena perilaku korupsi yang dilakukan oleh guru-guru di sekolah formal yayasan tersebut. Hasil penelitian pendahuluan menunjukkan salah satu bentuk perilaku yang ditunjukan oleh mereka antara lain penyuapan, nepotisme, penggunaan fasilitas 
yayasan untuk kepentingan pribadi. Perilaku tersebut termasuk termasuk perilaku korupsi sesuai dengan apa yang disampaikan KPK (2017). Meskipun perilaku korupsi yang dilakukan para guru itu dalam skala kecil, namun korupsi dalam skala besar biasanya umumnya berangkat dari korupsi dalam skala kecil (Huntington \& Fukuyama, 2006).

Yang menarik perilaku korupsi itu dilakukan di tempat diajarkannya ilmu agama, dan dilakukan oleh orang-orang yang belajar dan mengajarkan ilmu agama yang jelas-jelas mengajarkan perilaku anti korupsi. Bagaimana hal ini bisa terjadi, secara teoritis dan praktis perlu dicari penjelasannya.

Penelitian sebelumnya tentang relasi antara religiusitas dan perilaku korupsi memang tidak konsisten. Penelitian Kilkon Ko dan Seong-Gin Moon (2014) menunjukkan tidak ada hubungan antara religiusitas dan perilaku korupsi. Sementara itu penelitian Zuhaira dan Tian Ye-zhuang (2017) menunjukkan hasil yang sebaliknya, yaitu bahwa keyakinan beragama memiliki hubungan negatif dengan tingkat korupsi.

Munculnya perilaku anti korupsi, seseorang akan terlebih dahulu didorong oleh niatan berperilaku anti korupsi, atau dalam istilah lain dikenal sebagai intensi (Ajzen, 2005). Intensi sendiri adalah niat seseorang untuk memunculkan suatu perilaku (Ancok dkk., 2001). Menurut Ajzen (1991), intensi menggambarkan faktor motivasional yang mempengaruhi perilaku. Intensi mengindikasikan seberapa keras seseorang mencoba dan seberapa banyak upaya yang dilakukan untuk menampilkan suatu perilaku. Apabila intensi anti korupsi seseorang kuat maka kecenderungan berperilaku korupsi lebih kecil, begitupun sebaliknya. Apabila intensi anti korupsi seseorang rendah maka kecenderungan berperilaku korupsi lebih besar.

Dalam Theory of Planned Behavior (TPB) intensi muncul sebelum perilaku, dan sebelum intensi ada 3 faktor yang mempengaruhinya. Ketiga faktor tersebut adalah sikap (attitude toward behavior) yaitu keyakinan mengenai konsekuensi suatu perilaku. Keyakinan ini didapatkan dari penilaian subjektif individu. Untuk berintensi anti korupsi individu menilai anti korupsi itu sendiri ditinjau dari untung rugi yang akan diperolehnya. Faktor kedua norma subjektif (subjective norm) yaitu persepsi individu terhadap harapan dari orang-orang yang berpengaruh dalam kehidupannya mengenai dilakukan atau tidak dilakukannya suatu perilaku. Individu melakukan penilaian terhadap harapan orang lain, artinya bagaimana pandangan orang lain jika ia anti korupsi. Faktor terakhir persepsi kontrol perilaku (perceived behavioral control) yaitu persepsi individu tentang mudah sukarnya mewujudkan suatu perilaku. Dalam hal ini individu mempersepsikan perilaku anti korupsi sebagai hal yang mudah atau sulit dicapai olehnya (Ajzen, 1991). 
Humaira Mumtazah dkk. | Religiusitas dan Intensi Anti Korupsi

Faktor yang pertama yaitu sikap (attitude toward behavior) dapat diperoleh melalui keyakinan yang seseorang dapatkan selama rentang hidupnya. Salah satu keyakinan tersebut adalah nilai-nilai agama yang dianutnya. Konsep ini selanjutnya dijelaskan melalui religiusitas. Menurut Zuckerman, Silberman, dan Hall (2013) religiusitas adalah tingkat keterlibatan individu terhadap aspek-aspek agama. Ajaran agama memuat aturan-aturan mengenai apa yang seharusnya dilakukan dan yang tidak boleh dilakukan dengan pertimbangan dosa dan pahala. Orang yang religius melibatkan dirinya secara menyeluruh terhadap agamanya. Ancok dan Suroso (2001) menyebutkan religiusitas adalah keberagamaan yang meliputi berbagai dimensi yang bukan terjadi ketika seseorang melakukan perilaku ritual (ibadah), tapi juga melakukan aktivitas lain yang didorong oleh kekuatan supranatural. Ini berarti, dalam berperilaku individu mengaitkan segalanya dengan keyakinan dalam agama yang dianutnya. Agama juga dapat mencakup istilah etika, karena ia menjadi pengingat apa yang dianggap baik dan jahat (Sommer dkk., 2013).

Glock dan Starks (1965) dalam teorinya membagi religiusitas kedalam 5 dimensi, salah satunya adalah pengetahuan (knowledge) yang mengukur tingkat pengetahuan terhadap agama dan seberapa jauh usaha untuk menambahnya. Misalnya belajar AlQur'an, Al-Hadis, ilmu akhlak, dan sebagainya. Dimensi yang lain adalah konsekuensi (consequential). Dimensi ini mengukur sejauh mana ajaran agama mempengaruhi perilaku dalam kehidupan. Tingkat religusitas tercermin dalam perbuatannya yang sesuai dengan perintah serta larangan agama. Dimensi ini menegaskan bahwa religiusitas tidak selesai pada seluas apa pengetahuan dan pemahaman tentang agama atau pengalaman pribadi keimanannya saja, tapi juga tercermin dari aplikasi terhadap ajaran agama dalam kehidupan sehari-harinya.

Perilaku korupsi adalah perilaku yang bertentangan dalam ajaran agama, khususnya agama Islam. Mengambil sesuatu yang bukan hak milik kita atau merugikan pihak lain dapat berujung menjadi dosa. Religiusitas dapat menghilangkan niat untuk korupsi dan menumbuhkan niat untuk anti terhadap korupsi. Fenomena yang ditemukan menunjukkan bahwa meskipun posisi mereka merangkap sebagai pengajar ilmu agama yang mengindikasikan keluasan ilmunya daripada yang lain, akan tetapi belum tercermin dalam perilaku anti korupsinya. Mereka masih melakukan perilaku korupsi yang kemungkinan menunjukkan tidak adanya intensi anti korupsi.

Penelitian terdahulu mengenai dua variabel ini pun menunjukkan hasil yang beragam. Zuhaira dan Ye-zhuang (2017) meneliti pengaruh keyakinan beragama dan nilai korupsi pada 600 pegawai di Irak. Penelitian ini menunjukkan korelasi negatif antara 
keduanya, artinya religiusitas tidak dapat menjadi penghubung korupsi. Shadabi (2013) meneliti tentang pengaruh agama terhadap korupsi yang diperoleh dari data 174 negara tahun 2010. Faktor yang mempengaruhi korupsi salah satunya adalah agama, kecuali agama Islam dan Kristen. Tidak terdapat pengaruh yang signifikan terhadap korupsi bagi kedua agama ini. Elcar (2015) meneliti tentang religiusitas dan pemahaman perilaku korupsi (suap menyuap) terhadap 71 PNS Dinas X Kabupaten Mojokerto. Hasilnya tidak ada hubungan antara religiusitas dan korupsi. Variabel religiusitas tidak dapat menjelaskan varian pemahaman terhadap perilaku korupsi.

Disamping itu, penelitian Yahya, dkk (2015) menunjukkan hasil yang berbeda. Penelitian tersebut mencari korelasi antara budaya organisasi, religiusitas, dan korupsi pada persepsi generasi Y di Malaysia. Generasi Y digambarkan sebagai generasi yang muda dan cerdas, sehingga mereka lebih kritis dan analitis terhadap kondisi sosial ekonomi. Penelitian ini menunjukkan bahwa ada pengaruh budaya organisasi dan religiusitas terhadap korupsi. Agama mempengaruhi perilaku dan sikap manusia, sehingga pengaruh agama terhadap korupsi erat. Selain itu, Nihayah, Andriani, dan Wahyuni (2015) melakukan penelitian mengenai hubungan orientasi religius, integritas moral, kepribadian, iklim organisasi, dan intensi anti korupsi di Indonesia. Subjek penelitian ini adalah 203 PNS di departemen agama. Hasilnya semua variabel independen membawa pengaruh terhadap dependen variabel.

Wahyudi dan Sopanah (2004) menyebutkan bahwa perilaku korupsi bisa terjadi karena adanya dorongan dalam diri pelaku korupsi. Dorongan tersebut mengacu pada keinginan, niat, dan kesadaran untuk melakukan tindakan. Faktor yang bisa menyebabkan seseorang memiliki dorongan berkorupsi diantaranya adalah pengimplementasian ajaran agama yang kurang atau tidak benar. Nilai-nilai ajaran agama akan tercermin pada perilaku orang dengan religiusitas tinggi. Ia mampu menginternalisasi apa yang baik dan apa yang buruk menurut agamanya sehingga ia akan berusaha menghindari perbuatan korupsi. Faktor lain yang menyebabkan dorongan melakukan korupsi adalah lemahnya pegangan moral, gaya hidup yang berlebihan atau konsumtif, terdesak oleh kebutuhan, serta adanya sifat tamak dalam diri manusia.

Terjadinya tindakan korupsi mengindikasikan adanya motif internal ketidakpuasan (ketamakan) atas apa yang didapatkan. Rasa kepuasan terhadap sesuatu ini erat kaitannya dengan konsep kebersyukuran atau gratitude. Kebersyukuran diartikan sebagai suatu sikap menghargai setiap kehidupan sebagai karunia dan menyadari pentingnya mengungkapkan penghargaan tersebut (Watkins, 2013). Kebersyukuran merupakan atribut dasar dan kunci penting dalam pertumbuhan manusia (Emmons, 
Humaira Mumtazah dkk. | Religiusitas dan Intensi Anti Korupsi

2004). Orang yang bersyukur akan merasa hidupnya tercukupi dan tak kekurangan (sense of abundance) (Watkins, 2013). Syukur juga bukan hanya berupa perasaan yang hadir dalam diri individu, namun harus disertai dengan respon eksternal berupa lisan atau perbuatan (Rusdi, 2016). Perilaku syukur terarah pada kecenderungan kebaikan, karena sebagai ekpresi dari penghargaan atas yang didapatkan, sehingga orang yang bersyukur seharusnya tidak melakukan korupsi. Korupsi bertentangan dengan penghargaan tersebut, sebab korupsi berdampak pada kerugian besar bagi orang lain.

Beberapa penelitian menyatakan adanya korelasi positif antara religiusitas dengan kebersyukuran. Lambert, dkk (2009) meneliti adanya hubungan positif antara ibadah ritual dengan kebersyukuran. Subjek menganggap bersyukur adalah bagian dari ibadah harian, dengan begitu mereka sering merenungkan apa yang mereka syukuri. Orang menjadi lebih memperhatikan apa yang ada di sekitarnya, misalnya keindahan alam atau nikmat bernapas, yang merupakan karunia dari Sang Pencipta. Tsang dkk (dalam Froh dkk., 2011) menyatakan adanya hubungan religius intrinsik dengan gratefull disposition (gratitude sebagai affective trait) dan mendorong seseorang untuk mengekspresikan penghargaan. Sementara itu, emosi dan kecenderungan syukur berkorelasi dengan ibadah ritual serta self-transendence (Emmons, 2004).

Dari sini dapat ditemukan bahwa adanya keterkaitan antara kebersyukuran, religiusitas, dan intensi anti korupsi. Kebersyukuran dapat menjadi variabel moderator sebab individu akan lebih mensyukuri apa yang ada saat ini dan membuat religiusitasnya menguat, dimana syukur merupakan salah satu bentuk ibadah. Ungkapan syukur juga dibuktikan dengan perbuatan baik atau prososial sehingga akan memiliki intensi anti korupsi. Oleh karena itu, peneliti tertarik untuk meneliti 'Kebersyukuran sebagai variabel moderator antara hubungan religiusitas dengan intensi anti korupsi'.

\section{METODE}

Penelitian ini termasuk penelitian korelasional. Yaitu, penelitian yang bertujuan untuk mengidentifikasi hubungan antar variabel (Rahman, 2016). Variabel-variabel yang menjadi focus penelitian adalah religiusitas sebagai variabel eksogen, intensi anti korupsi sebagai variabel endogen, dan kebersyukuran sebagai variabel moderator.

Subjek penelitian ini merupakan seluruh guru dan staf yang berada di salah satu yayasan pendidikan di Kabupaten Garut. Subjek penelitian seluruhnya berjumlah 92 orang. Data penelitian dikumpulkan dengan menggunakan tiga skala. Ada skala kebersyukuran yang dinamai dengan GRAT Short Form dari Watkins (2013). Dinamakan demikian karena skala ini merupakan hasil revisi dari skala kebersyukuran versi panjang 
yang dibuat Watkins sebelumnya. Skala ini mengukur kebersyukuran ditinjau dari ciri-ciri orang bersyukur, yang terdiri dari 16 item. Uji reliabilitas menunjukkan nilai koefisien alpha untuk alat ukur Kebersyukuran (M) sebesar 0.82 .

Ada Muslim Religiosity Scale (MRS) yang digunakan untuk mengukur religiusitas. MRS dibuat oleh El Menouar pada tahun 2014. MRS digunakan untuk mengukur sejauh mana tingkat religiusitas seseorang ditinjau dari 5 dimensi religiusitas, yaitu basic religiosity, ritual and devotion, experience, knowledge, dan orthopraxis. MRS terdiri dari 46 butir pernyataan. Uji reliabilitas menunjukkan nilai koefisien alpha sebesar 0.93 . Terakhir ada skala intensi anti korupsi yang disusun oleh Nihayah, Andriani, dan Wahyuni pada tahun 2015. Skala ini tersusun berdasarkan jenis-jenis korupsi. Yaitu anti suap (anti bribe), anti gratifikasi (anti-gratification), anti curang (anti-fraud), anti penggelembungan (anti-mark up), anti pemerasan (anti-black mail), dan anti nepotisme (anti-nepotism). Item-itemnya dimodifikasi agar bisa sesuai dengan latar belakang profesi subjek penelitian, yaitu guru dan staf. Peneliti pun menambahkan delapan item baru, yang awalnya terdiri dari 12 item, menjadi 20 item. Uji reliabilitas menunjukkan nilai koefisien alpha sebesar 0.87 .

Dengan menggunakan ketiga skala tersebut, data penelitian diambil secara langsung kepada seluruh subjek penelitian, yang merupakan guru dan staf. Skala diberikan kepada guru di saat ada jadwal mengajar, sedangkan kepada staf diberikan secara serentak. Guru dan staf diminta untuk diisi dan dikumpulkan langsung setelah selesai.

Uji regresi berganda. Moderated Regression Analysis (MRA) dipakai untuk menguji hubungan antar variabel penelitian. MRA ini merupakan suatu teknik statistik yang biasa digunakan untuk menganalisis hubungan antara satu variabel dependen (kriterion) tunggal dan beberapa variabel independen (prediktor), yang antar variable preditornya terdapat interaksi. Hal Ini sesuai dengan tujuan penelitian yang ingin mengetahui kekuatan kebersyukuran sebagai variabel moderasi terhadap hubungan antara religiusitas dengan intensi anti korupsi.

\section{PAPARAN HASIL}

Kategori subjek penelitian. Pada bagian ini akan dipaparkan kategorisasi subjek pada setiap variabel penelitian, yaitu kebersyukuran, religiusitas, serta intensi anti korupsi. Pembuatan kategori subjek ini berdasarkan hasil analisis deskriptif. 
Humaira Mumtazah dkk. | Religiusitas dan Intensi Anti Korupsi

Tabel 1

Kategori subjek penelitian berdasarkan variabel penelitian

\begin{tabular}{lcc}
\hline \multirow{2}{*}{ Variabel } & \multicolumn{2}{c}{ Kategori } \\
\cline { 2 - 3 } & Tinggi & Rendah \\
\hline Kebersyukuran & $57(68 \%)$ & $35(38 \%)$ \\
\hline Religiusitas & $60(65.2 \%)$ & $32(34.8 \%)$ \\
\hline Intensi anti korupsi & $49(53.3 \%)$ & $43(46.7 \%)$ \\
\hline
\end{tabular}

Tabel 1 menunjukkan bahwa pada variabel kebersyukuran dan religiusitas, subjek umumnya termasuk pada kategori tinggi dengan persentase berturut-turut $68 \%$ dan $65 \%$. Sementara itu, pada variabel intensi anti korupsi subjek pada umumnya termasuk tinggi namun tingkat perbedaannya tidak terlalu signifikan dengan subjek yang rendah intensi anti korupsinya. Persentasenya adalah sebesar 53.3\% untuk subjek kategori intensi anti korupsi tinggi dan $46.7 \%$ untuk subjek kategori intensi anti korupsi rendah.

Uji regresi berganda. Sebelum melakukan uji hipotesis, dilakukan uji asumsi klasik. Hasilnya menunjukkan bahwa data penelitian bersifat normal ( $p>.005$ ), tidak terdapat multikolinieritas (VIF < 10.00), dan hubungan antar variabel bersifat linier.

Langkah berikutnya dilakukan uji regresi dengan uji interaksi Moderated Regression Analysis (MRA) dengan menggunakan SPSS versi 21. Cara menghitungnya terbagi menjadi dua (2) tahap. Tahap pertama adalah uji regresi sederhana untuk mencari hubungan antara variabel religiusitas dengan intensi anti korupsi. Didapatkan nilai $\mathrm{F}$ sebesar 154.1, nilai signifikansi sebesar .001, dan nilai $\mathrm{R}^{2}$ sebesar .631. Jadi, religiusitas berpengaruh positif terhadap intensi anti korupsi.

Tahap kedua adalah pengujian pengaruh variabel kebersyukuran terhadap hubungan antara religiusitas dan intensi anti korupsi. Pertanyaan yang ingin dijawab adalah apakah dengan dimasukannya kebersyukuran sebagai variable moderator, apakah pengaruh religiusitas terhadap intensi anti korupsi itu meningkat atau menurun.

Untuk menjawab pertanyaan tersebut, bisa dilakukan dengan membandingkan antara nilai $\mathrm{R}$ pengaruh religiusitas terhadap intensi anti korupsi sebelum ditambahkan variabel kebersyukuran $\left(\mathrm{R}^{1}=.631\right)$, dan setelah ditambahkan variable kebersyukuran $\left(\mathrm{R}^{2}=\right.$ .668). Hasilnya menunjukkan adanya peningkatan nilai $\mathrm{R}$ sebesar .037, setelah ditambahkan variabel kebersyukuran. Artinya, kebersyukuran dapat meningkatkan hubungan religiusitas terhadap intensi anti korupsi. 
Humaira Mumtazah dkk. | Religiusitas dan Intensi Anti Korupsi

\section{PEMBAHASAN}

Dalam perspektif Islam, niat merupakan salah satu faktor penting yang berpengaruh terhadap perilaku. Nabi Muhammad saw. bersabda bahwa seluruh perbuatan tergantung pada niat (al-Bukhari, 2015). Jadi, niat diyakini sebagai faktor yang berpengaruh terhadap perilaku seseorang. Demikian juga dengan intense anti-korupsi diyakini sebagai salah satu yang berpengaruh terhadap perilaku korupsi.

Hasil penelitian ini menunjukkan adanya hubungan positif antara religiusitas dan intensi anti korupsi. Arah dari hubungan ini bersifat positif yang artinya tingginya religiusitas seseorang berhubungan dengan tingginya intensi untuk melakukan perilaku anti korupsi. Hasil ini mendukung penelitian sebelumnya yang menyatakan ada hubungan antara keduanya. Nihayah, Andriani, dan Wahyuni (2015) menyebutkan intensi anti korupsi berhubungan dengan beberapa variabel yaitu orientasi religius, integritas moral, kepribadian, dan iklim organisasi. Hasil penelitian ini juga sejalan dengan penelitian sebelumnya. Penelitian Yahya (2015) menunjukkan bahwa religiusitas berpengaruh terhadap sikap dan perilaku seseorang, termasuk sikap dan perilaku korupsi dalam lingkup organisasi.

Penelitian Wahyudi dan Sopanah (2004) menunjukkan bahwa perilaku korupsi bisa terjadi karena adanya dorongan dalam diri pelaku korupsi, yang salah satunya adalah niat atau intensi. Intensi sendiri dapat muncul dipengaruhi oleh beberapa faktor yaitu faktor internal dan faktor eksternal (Ajzen, 2005). Menurut Ajzen (2005), faktor internal yang mempengaruhi intensi antara lain norma subjektif, sikap, dan keyakinan bahwa dirinya mampu melakukan sesuatu. Agama adalah merupakan keyakinan yang mungkin diinternalisasikan sebagai norma subjektif seseorang yang dipakai dalam melakukan penilaian, dan penilaian ini kemudian akan berpengaruh terhadap nilai. Agama yang diidentifikasikan dalam diri seseorang bisa juga membantunya dalam menghadapi berbagai permasalahan hidup sehingga terhindar dari perilaku-perilaku yang bertentangan dengan nilai agama, salah satunya perilaku korupsi (Azkiati Z dkk., 2019).

Selanjutnya, penelitian ini juga menunjukkan bahwa kebersyukuran dapat meningkatkan hubungan antara religiusitas dan intensi anti-korupsi. Kebersyukuran memang salah satu karakteristik penting bagi seseorang yang religious. Tsang dkk (dalam Froh dkk., 2011) yang menemukan korelasi religius intrinsik dengan syukur disposisi (kebersyukuran sebagai affective trait). Syukur merupakan satu karakter yang dianjurkan dalam agama sehingga saat seseorang melakukan syukur religiusitasnya ikut tumbuh sebagai perwujudan konsekuensi dari beragama. Lambert (2009) juga menemukan hal yang hampir serupa. Salah satu dimensi religiusitas yaitu ibadah ritual berhubungan 
Humaira Mumtazah dkk. | Religiusitas dan Intensi Anti Korupsi

dengan kebersyukuran. Seseorang akan menganggap bersyukur adalah bagian dari ibadah harian, dengan begitu ia sering merenungkan apa yang ia syukuri. Seseorang menjadi lebih memperhatikan apa yang ada di sekitarnya, misalnya keindahan alam, menghargai makanan yang dimiliki, dan seterusnya.

Dalam Teori GONE (Bologna, 1993) seseorang bisa melakukan tindakan curang, dalam hal ini korupsi, disebabkan adanya kecenderungan keserakahan atau ketamakan (greed) dalam diri manusia. Kecenderungan negatif ini dapat teredam melalui karakter positif kebersyukuran. Bahkan Emmons (2004) menyebutkan kebersyukuran adalah atribut dasar dan kunci penting dalam pertumbuhan manusia. Pernyataan tersebut sesuai dengan karakter kebersyukuran yang mengarahkan seseorang pada kecenderungan dan perilaku prososial. Salah satu karakter kebersyukuran adanya perasaan bahwa dirinya dilimpahi oleh karunia dan tidak kekurangan. Mereka juga sangat menyadari dan menghargai bantuan orang lain sehingga dari perasaan dan kesadaran itu timbul keinginan untuk mengekspresikan kebersyukuran dalam sesuatu yang baik. Salah satunya bisa berupa kecenderungan dan perilaku anti korupsi sebab korupsi merupakan perilaku yang dapat merugikan orang lain. Hal ini bertentangan dengan ekspresi kebersyukuran tersebut.

Kebersyukuran tidak serta merta terjadi begitu saja. Kebersyukuran dapat tumbuh seiring dengan pendidikan yang baik dari significant other dan lingkungannya. Watkins (2013) memaparkan faktor yang mendukung tumbuhnya karakter kebersyukuran adalah perkembangan kognisi, gaya kelekatan aman, dan pola asuh. Apabila dikerucutkan kesemuanya bisa dimasukkan dalam kategori pendidikan keluarga. Karakter seorang anak yang tumbuh dalam kelekatan aman biasanya memiliki pandangan positif terhadap diri dan orang lain, karakter ini bisa menjadi pondasi kebersyukuran yang menerima secara positif perbuatan baik orang lain kepadanya. Seorang anak yang tumbuh dalam pola asuh kebersyukuran juga meniru perilaku-perilaku kebersyukuran seperti mengucapkan 'terimakasih'atau saat anak tersebut mengekspresikan kebersyukuran ia mendapat apresiasi dari orangtua. Pola asuh juga akhirnya akan mempengaruhi perkembangan kognisi tentang kebersyukuran tersebut. Salah satu faktor tersebut pula yang mungkin mempengaruhi subjek dalam penelitian ini.

Walaupun hipotesis penelitian ini terbukti. Namun, ada beberapa kekurangan yang bisa diperbaiki oleh peneliti berikutnya. Walaupun menggunakan semua anggota populasi sebagai subjek penelitian, tapi jumalah subjek penelitian ini tidak terlalu banyak. Jumlah subjek yang banyak dipastikan akan variatif, dan akan berdampak terhadap hasil penelitian. Berikutnya, perilaku korupsi juga dipengaruhi oleh faktor eksternal. Peneliti 
berikutnya disarankan untuk meneliti faktor eksternal terhadap intensi ataupun perilaku korupsi.

\section{SIMPULAN}

Berdasarkan hasil penelitian yang telah dilakukan maka dapat disimpulkan bahwa terdapat hubungan positif antara religiusitas dengan intensi anti korupsi. Semakin tinggi tingkat religiusitas seseorang maka semakin tinggi pula tingkat intensi anti korupsinya. Selain itu, kebersyukuran memiliki pengaruh sebagai variabel moderator pada hubungan religiusitas dengan intensi anti korupsi. Kebersyukuran dapat menaikkan tingkat korelasi religiusitas dengan intensi anti korupsi. semakin tinggi kebersyukuran semakin tinggi pula hubungan keduanya.

\section{DAFTAR PUSTAKA}

Abdulkareem, M., Zuhaira, M., \& Ye-Zhuang, T. (2017). The Effect of Religious Beliefs, Participation and Values on Corruption: Survey Evidence from Iraq. Dalam IJACSA) International Journal of Advanced Computer Science and Applications (Vol. 8, Nomor 8).

Ajzen, I. (1991). The theory of planned behavior. Organizational Behavior and Human Decision Processes, 50(2), 179-211. https://doi.org/10.1016/07495978(91)90020-T

Ajzen, I. (2005). From Dispositions to Actions. Dalam T. Manstead (Ed.), Attitudes, Personality and Behavior (hlm. 41-70). McGraw-Hill Education.

al-Bukhari, M. bin I. (2015). Shahih al-Bukhari. Darul Kitab al-'Ilmiyah.

Ancok, D., Suroso, F., \& Ardani, M. (2001). Psikologi islami: Solusi islam atas problemproblem psikologi. Pustaka Pelajar.

Azkiati Z, N. Z., Rahman, A. A., \& Fahmi, I. (2019). Predict Burnout With Psychological Capital And Religious Coping. Psikis : Jurnal Psikologi Islami, 5(2), 140-145.

Bologna, J. (1993). Handbook on corporate fraud: Prevention, detection, and investigation. Butterworth-Heinemann. https://trove.nla.gov.au/version/45137091

Elcar, V. (2015). Hubungan Antara Religiositas dengan Pemahaman Terhadap Perilaku Korupsi [Thesis, UII Yogyakarta]. https://dspace.uii.ac.id/handle/123456789/1362

Emmons, R. A. (2004). The Psychology of Gratitude: An Introduction. Dalam The psychology of gratitude. (hlm. 3-16). Oxford University Press. https://doi.org/10.1093/acprof:oso/9780195150100.003.0001

Froh, J. J., Fan, J., Emmons, R. A., Bono, G., Huebner, E. S., \& Watkins, P. (2011). Measuring gratitude in youth: Assessing the psychometric properties of adult gratitude scales 
Humaira Mumtazah dkk. | Religiusitas dan Intensi Anti Korupsi

in children and adolescents. Psychological Assessment, 23(2), 311-324. https://doi.org/10.1037/a0021590

Glock, C. Y., \& Stark, R. (1965). Religion and society in tension. Rand McNally.

Huntington, S. P., \& Fukuyama, F. (2006). Political order in changing societies. Dalam Political Order in Changing Societies. Yale University Press. https://doi.org/10.5771/0506-7286-1970-2-257

Ko, K., \& Moon, S.-G. (2014). The relationship between religion and corruption: Are the proposed causal links empirically valid? International Review of Public Administration, 19(1), 44-62. https://doi.org/10.1080/12294659.2014.887353

Kompas.com. (2018). 2.357 Koruptor Berstatus PNS, Ini Detail Berdasarkan Instansi dan Daerah. $\quad$ https://nasional.kompas.com/read/2018/09/13/20472451/2357koruptor-berstatus-pns-ini-detail-berdasarkan-instansi-dan-daerah

KPK. (2017, Desember 8). Undang Undang Terkait. https://www.kpk.go.id/id/tentangkpk/undang-undang-terkait

Lambert, N. M., Graham, S. M., Fincham, F. D., \& Stillman, T. F. (2009). A changed perspective: How gratitude can affect sense of coherence through positive reframing. The Journal of Positive Psychology, 4(6), 461-470. https://doi.org/10.1080/17439760903157182

Rahman, A. A. (2016). Metode Penelitian Psikologi: Langkah cerdas menyelesaikan skripsi. PT Remaja Rosdakarya Offset-Bandung.

Rusdi, A. (2016). Syukur dalam Psikologi Islam dan Konstruksi Alat Ukurnya. Jurnal Ilmiah Penelitian Psikologi: Kajian Empiris \& Non-Empiris, 2(2), 37-54. https://doi.org/10.22236/JIPP-19

Sekretariat Kabinet Republik Indonesia. (2018, Januari 8). APBN 2018: Total Anggaran Pendidikan Rp444,131 Triliun, Terbanyak di Kemenag Rp52,681 Triliun. https://setkab.go.id/apbn-2018-total-anggaran-pendidikan-rp444131-triliunterbanyak-di-kemenag-rp52681-triliun/

Shadabi, L. (2013). The Impact of Religion on Corruption. The Journal of Business Inquiry, $12,117$.

Sommer, U., Bloom, P. B.-N., \& Arikan, G. (2013). Does faith limit immorality? The politics of religion and corruption. Democratization, 20(2), 287-309. https://doi.org/10.1080/13510347.2011.650914

Sopanah, S., \& Wahyudi, I. (2004). Analisa Anggaran Publik: Panduan TOT. Malang Corruption Watch (MCW) dan Yappika.

Wahyuni, Z. I., Adriani, Y., \& Nihayah, Z. (2015). The Relationship between Religious Orientation, Moral Integrity, Personality, Organizational Climate and Anti Corruption Intentions in Indonesia. International Journal of Social Science and Humanity, 5(10), 860-864. https://doi.org/10.7763/IJSSH.2015.V5.570 
Watkins, P. C. (2013). Gratitude and the Good Life: Toward a Psychology of Appreciation (2014 editi). Springer.

Yahya, K. K., Yean, T. F., Johari, J., \& Saad, N. A. (2015). The Perception of Gen Y on Organizational Culture, Religiosity and Corruption in Malaysian Public Organizations. Procedia Economics and Finance, 31, 251-261. https://doi.org/10.1016/S2212-5671(15)01227-7

Zuckerman, M., Silberman, J., \& Hall, J. A. (2013). The Relation Between Intelligence and Religiosity. Personality and Social Psychology Review, 17(4), 325-354. https://doi.org/10.1177/1088868313497266 